\title{
CONSIDERAÇÕES ACERCA DO PROGRAMA NACIONAL DE FORTALECIMENTO DA AGRICULTURA FAMILIAR (PRONAF) NO PROJETO DE ASSENTAMENTO SANTA ROSA EM ITAQUIRAÍ - MS
}

\author{
Considerations about of the National Program for Strengthening Family \\ Agriculture (PRONAF) in the Santa Rosa settlement project in Itaquiraí - MS
}

\author{
Vania Olmedo Moura dos Santos \\ Licenciada em Educação do Campo, UFGD \\ vaniasantos9842@hotmail.com \\ Rodrigo Simão Camacho \\ Professor da Licenciatura em Educação do Campo, UFGD \\ rodrigocamacho@ufgd.edu.br \\ Cristiano Almeida da Conceição \\ Doutorando em Geografia, UFGD \\ cris87almeida@gmail.com
}

Recebido em 15/07/2020

\section{Aceito em 13/11/2020}

RESUMO: Este artigo tem por objetivo analisar os efeitos do Programa Nacional de Fortalecimento da Agricultura Familiar (Pronaf) na produção agrícola, na geração de emprego e renda no assentamento Santa Rosa, localizado no Município de Itaquiraí/MS. Após uma fundamentação teórica sobre o Pronaf e agricultura camponesa ${ }^{1}$ sob a ótica da sustentabilidade, apresenta-se os resultados da pesquisa, a qual fora construída a partir de uma abordagem quali/quantitativa baseada em um estudo de caso, com entrevistas e questionários semiestruturados realizadas com os beneficiários do Programa. A partir desta foi possível concluir que o Pronaf contribuiu para o desenvolvimento territorial com sustentabilidade ao elevar a renda, fortalecer a capacidade produtiva da agricultura camponesa e estimular a manutenção local da atividade agrícola de pequena escala, ainda que conte com diversas limitações em relação à sua operação e manutenção.

Palavras-chave: Pronaf; Agricultura Camponesa; Desenvolvimento Territorial.

ABSTRACT: This article aims to analyze the effects of the National Program for Strengthening Family Farming (Pronaf) on agricultural production, job and income generation in the Santa Rosa settlement, located in the Municipality of Itaquiraí / MS. After a theoretical foundation on Pronaf and peasant agriculture from the perspective of sustainability, the results of the research are presented, which was built from a quali / quantitative approach based on a case study, with interviews and semi-structured questionnaires conducted with beneficiaries of the Program. From this it was possible to conclude that Pronaf contributed to territorial development with sustainability by raising income, strengthening the productive capacity of peasant agriculture and encouraging the local maintenance of small-scale agricultural activity, even though it has several limitations in relation to its operation and maintenance.

Keywords: Pronaf; Peasant Agriculture; Territorial Development.

\footnotetext{
${ }_{1}^{1}$ Vamos utilizar este conceito, tendo em vista que as relações sociais que denominamos de agricultura camponesa, na perspectiva paradigmática do PRONAF, é denominada de agricultura familiar. Sendo assim, não teremos a intenção neste texto de debater as diferenças das matrizes paradigmáticas que embasam estes dois conceitos, utilizando-o, portanto, como sinônimo de toda unidade de produçãoconsumo que tenha como elementos centrais, a terra e o trabalho familiar, entre estes, os camponesesassentados, sujeitos de nossa pesquisa.
}

REVISTA GEONORTE, V.11, N.38, p.200-223, 2020.

(ISSN 2237 - 1419) 
CONSIDERAÇÕES ACERCA DO PROGRAMA NACIONAL DE FORTALECIMENTO DA AGRICULTURA FAMILIAR (PRONAF) NO PROJETO DE ASSENTAMENTO SANTA ROSA EM ITAQUIRAÍ - MS

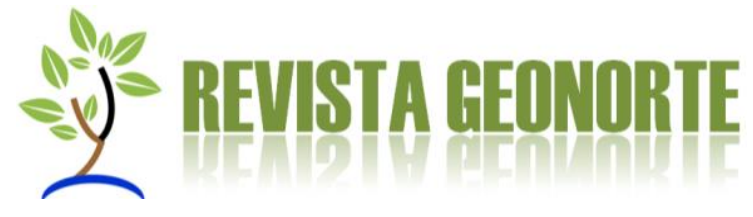

\section{INTRODUÇÃO}

O Programa de Fortalecimento de Agricultura Familiar (Pronaf) nasceu por meio da Resolução 2.141, de 24 de agosto de 1995 e foi institucionalizado no ano seguinte pelo decreto presidencial de oㅜ 1.946 de 28/07/96, durante a vigência do primeiro mandato do Governo de Fernando Henrique Cardoso FHC (1995-1998). O programa Pronaf resulta do aperfeiçoamento do antigo Programa de Valorização da Pequena Produção Rural (PROVAP) criado ainda no governo de Itamar Franco (1992-1995). Nasce em uma época em que a carência de crédito estava entre os maiores problemas que os agricultores enfrentavam.

Após 22 anos de existência o programa Pronaf se ramificou de forma considerável por todo o território nacional. Embora são perceptíveis a evolução e a ampliação no montante de recursos disponibilizados para financiar a produção agropecuária, o programa ainda apresenta limitações no acesso para muitos agricultores no momento de contratar os financiamentos. Nesta conjuntura, Corrêa e Ortega destacam que o Pronaf seria uma ferramenta de democratização dos recursos, viabilizando o crédito para os pequenos agricultores descapitalizados, mas não é isso que os dados têm demonstrado.

O que se verifica é que prevaleceu essencialmente a mesma lógica de liberação do modelo pretérito, sendo que foram estipuladas normas específicas que dificultam a tomada do crédito pelos produtores familiares menos integrados, principalmente no que tange às garantias exigidas (CÔRREA; ORTEGA 2002, p.11).

A liberação de recursos é feita diretamente entre o banco e o demandante de crédito. As críticas estão, principalmente, relacionadas ao próprio modelo de desenvolvimento em que as políticas públicas estão inseridas e na forma de relacionamento com os seus beneficiários.

Desta forma, a pesquisa tem por objetivo de analisar como o Programa Nacional de Fortalecimento da Agricultura familiar (Pronaf) tem influenciado na vida socioeconômica dos agricultores do assentamento Santa Rosa (grupo MST), município de Itaquirai-MS.

A pesquisa foi desenvolvida no assentamento Santa Rosa, especificamente com produtores ligados ao trabalho familiar. Para esta pesquisa optou-se por realizar um estudo de caso qualitativo, que constitui no levantamento de informações e estudo a respeito da agricultura camponesa e sua importância para as famílias e a comunidade em geral.

\section{MATERIAIS E MÉTODOS}

A primeira etapa foi feita a partir de pesquisas bibliográficas em livros, periódicos, teses, dissertações etc. 
CONSIDERAÇÕES ACERCA DO PROGRAMA NACIONAL DE FORTALECIMENTO DA AGRICULTURA FAMILIAR (PRONAF) NO PROJETO DE ASSENTAMENTO SANTA ROSA EM ITAQUIRAÍ - MS

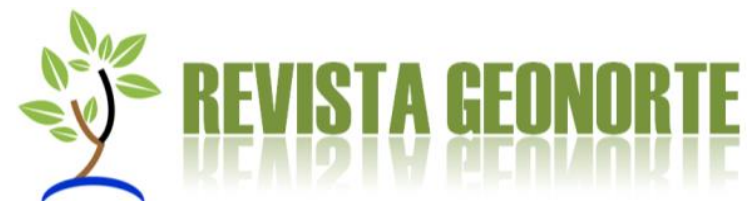

Na segunda fase, foi feito um levantamento sobre as famílias que utilizaram ou utilizam - Pronaf para que pudessem explicar as relações ocorridas desde os primeiros projetos implementados no lote até o período da pesquisa.

Foram realizadas entrevistas e aplicados questionários com roteiro semiestruturados (em apêndice), com 20 famílias do assentamento Santa Rosa, as quais foram beneficiadas com o Pronaf. Procurou-se entrevistar camponeses que acessaram o Pronaf em diferentes períodos e de linhas de financiamentos também.

Depois de aplicado o questionário, realizou-se a tabulação e apresentação dos dados utilizando um programa de planilha eletrônica, o qual permitiu a elaboração de tabelas e gráficos.

Por meio das respostas, buscamos analisar a produção camponesa para autoconsumo e o comércio do excedente no assentamento Santa Rosa, em Itaquiraí, Mato Grosso do Sul.

Além disso, também, foi realizado entrevista gravada em áudio com um representante da Agência de Desenvolvimento Agrário e Extensão Rural (Agraer) do município de Itaquirai/MS. Posteriormente, foi feita a transcrição na íntegra.

Também, utilizamos como fontes, a observação-participante, além de fotografias.

\section{RESULTADOS E DISCUSSÕES}

\section{A EVOLUÇÃO DAS POLÍTICAS PÚBLICAS VOLTADAS PARA A AGRICULTURA FAMILIAR/CAMPONESA NO BRASIL: O PRONAF EM QUESTÃO}

As políticas públicas seriam o Estado em ação, em formas de programas dando forma aos direitos constitucionais. Tais como os direitos sociais; educação, saúde, trabalho, moradia, lazer, segurança, previdência social, proteção à maternidade e à infância e assistência aos desamparados. Sendo o direito, universal, válido, para todos os indivíduos, grupos e classes sociais. A luta por direitos, é inerente à sociedade do capital e faz a desigualdade no acesso aos direitos transformar-se em fundamento para a demanda por reconhecimento das especificidades históricas que constituem esses sujeitos de direito. (MOLINA, 2012)

Schneider, Mattei e Cazella (2004) mencionam que a criação do Programa Nacional de Fortalecimento da Agricultura Familiar (Pronaf) tem sido marcante nas políticas públicas brasileiras, principalmente, porque o surgimento deste programa acabou por representar o reconhecimento e a legitimação do Estado, no que se refere aos agricultores familiares.

Quando se busca um conhecimento mais profundo sobre quais fatores corroboraram para a criação do Pronaf vale destacar os autores Schneider, Mattei e Cazella (2004) enfatizam sobre o contexto da agricultura brasileira na década de 1990.

É preciso lembrar que, no contexto do início da década de 1990, a agricultura brasileira, e particularmente a da região Meridional do Brasil, estava fortemente afetada pelo processo de abertura comercial e de desregulamentação dos mercados, fatores que a submetiam a uma concorrência intensa com os países do Mercosul. Em vista das sucessivas 
dificuldades decorrentes da crise da segunda metade dos anos oitenta, particularmente no que se refere à disponibilidade de crédito e da queda da renda, os agricultores familiares da região Sul do Brasil, e em menor medida os agricultores da região Nordeste (sobretudo os produtores de algodão), encontravam-se debilitados diante da nova conjuntura econômica e comercial. (SCHNEIDER; MATTEI; CAZELLA, 2004, p.22).

Diante disto, a história das políticas públicas rurais já vinha acontecendo há alguns anos na busca de melhores condições como descreve Bianchini (2015).

A política de crédito rural no Brasil foi o principal instrumento de fomento à modernização conservadora ocorrida a partir de meados dos anos 1960. Algumas Leis encaminhadas pelo Poder Executivo durante o Regime Militar (1964 a 1985) deram suporte a este processo de modernização da agricultura brasileira (BIANCHINI, 2015, p.15).

Entretanto, Bianchini (2015) menciona que a década de noventa teve em destaque alguns acontecimentos que foram primordiais para as mudanças no desenvolvimento rural, no que se refere a política governamental, pois os movimentos sociais do campo ligados aos sindicatos dos trabalhadores rurais que estavam atrelados à Confederação Nacional dos Trabalhadores da Agricultura (CONTAG) e, também, ao Departamento Nacional de Trabalhadores Rurais da Central Única dos Trabalhadores (DNTR/CUT), através de suas organizações, passaram a buscar por meio de reivindicações, que os agricultores familiares não fossem prejudicados pela iniciativa de abertura comercial da economia, pois havia um temor que após a criação do Mercosul, os pequenos agricultores fossem ainda mais marginalizados por falta de politicas publicas. Assim, as reivindicações dos trabalhadores rurais, que já tinha iniciado na Constituição de 1988, e teve grande evidência nas "Jornadas Nacionais de Luta", a partir de 1995 ficou conhecida como "Grito da Terra Brasil.

Portanto, os estudos que foram realizados pelo Projeto da $\mathrm{FAO}^{2} /$ Incra, determinaram com maior exatidão o que realmente se conceituava como a agricultura familiar e instituíram diversas diretrizes que serviriam como base para a construção de políticas específicas para os trabalhadores rurais, e consequentemente, serviu para primeiras formulações do Pronaf (SCHNEIDER; MATTEI; CAZELLA, 2004).

Noutras linhas Mattei (2005) menciona que os processos políticos de 1994 através do, então, Presidente Itamar Franco, passam a destinar créditos com juros acessíveis aos agricultores familiares por meio do o Programa de Valorização da Pequena Produção Rural (Provap):

[...] nota-se que esse processo de mudanças na política agrícola teve início a partir de 1994, quando o Governo Itamar Franco criou o Programa de Valorização da Pequena Produção Rural (Provap), que tinha como objetivo destinar um volume de crédito com taxas de juros mais acessíveis aos agricultores familiares. Cabe frisar que, embora o Provap tenha tido resultados pífios do ponto de vista dos recursos aportados para os agricultores, sua importância consiste na transição que ali se iniciou em direção a uma política pública diferenciada por categorias de produtores rurais. (MATTEI, 2005, p.145).

${ }^{2}$ Organização das Nações Unidas para a Alimentação e a Agricultura no mundo.

REVISTA GEONORTE, V.11, N.38, p.200-223, 2020.

DOI: 10.21170/geonorte.2020.V.11.N.38.200.223

(ISSN 2237 - 1419) 
Nesta direção, os autores Schneider, Mattei e Cazella (2004) descrevem que o Programa de Valorização da Pequena Produção Rural (Provap) foi reformulado no Governo Fernando Henrique Cardoso, dando origem ao Pronaf, através do Decreto Presidencial no 1.946, datado de 28/07/1996.

A partir de 1995, já no Governo Fernando Henrique Cardoso, o PROVAP foi totalmente reformulado, tanto em termos de concepção como em sua área de abrangência. Essas modificações deram origem ao PRONAF, em 1996, cuja institucionalização ocorreu através do Decreto Presidencial № 1.946, datado de 28/07/1996. Desse ano em diante, o programa tem se firmado como a principal política pública do Governo Federal para apoiar os agricultores familiares. Deve-se registrar, no entanto, que, no ano de 1996, apenas as ações relativas ao crédito de custeio foram implementadas e que a ampliação do programa para as áreas de investimentos, infra-estrutura e serviços municipais, capacitação e pesquisa, só ocorreu a partir de 1997, quando o PRONAF ganhou maior dimensão e passou a operar de forma integrada em todo território nacional. (BRASIL, 1996).

Neste sentido, Mattei (2005) menciona que o Manual Operacional do Pronaf passa a definir como objetivo geral deste programa a viabilização de condições para aumentar a produtividade, a geração de emprego e de renda, com ênfase na melhoria de qualidade de vida dos agricultores familiares, pois os objetivos do Programa eram os seguintes:

$\checkmark$ Criação e melhorias das políticas públicas condizente com a realidade dos agricultores familiares;

$\checkmark$ Melhoria na infraestrutura para maior desempenho produtivo dos agricultores familiares;

$\checkmark$ Viabilização de acesso aos novos padrões de tecnologia e de gestão social para elevar o nível de profissionalização dos agricultores familiares

$\checkmark$ Proporcionar estímulos ao acesso dos agricultores aos mercados de insumos e produtos. (MATTEI, 2005 p 145).

$\mathrm{Na}$ atualidade, o Pronaf possui diversas linhas de crédito, cada uma com sua respectiva finalidade e aporte de recursos, as quais podemos destacar:

- Pronaf custeio, com a finalidade do custeio de atividades agrícolas e pecuárias, inclusive aquisição de animais para recria e engorda.

- Pronaf Investimento (Mais Alimentos), Investimento da infraestrutura de produção e serviços agropecuários e não-agropecuários no estabelecimento rural.

- Pronaf Agroindústria, Investimento em atividades que agreguem renda à produção e aos serviços desenvolvidos pelos beneficiários do Pronaf.

- Pronaf floresta: Investimento para implantação de projetos de sistemas agro-florestais, exploração extrativista ecologicamente sustentável, plano de manejo e manejo -florestal.

- Pronaf semiárido: Investimento em infraestrutura hídrica $(50 \%$ do valor financiado) e demais infraestruturas de produção

- Pronaf jovem: Investimento para atividades agropecuárias, turismo rural, artesanato e outras atividades no meio rural.

- Pronaf Microcrédito da Reforma Agrária: Financiamento de atividades agropecuárias desenvolvidas no estabelecimento rural.

- Pronaf Mulher Grupo "B": Nas condições da linha Microcrédito Produtivo Rural - Grupo "B" 
CONSIDERAÇÕES ACERCA DO PROGRAMA NACIONAL DE FORTALECIMENTO DA AGRICULTURA FAMILIAR (PRONAF) NO PROJETO DE ASSENTAMENTO SANTA ROSA EM ITAQUIRAÍ - MS

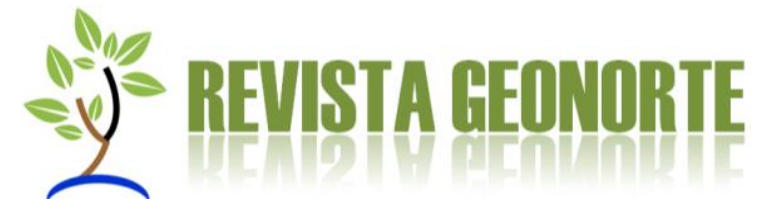

- Pronaf Mulher Investimento: Nas condições da linha Pronaf Investimento (Pronaf Mais Alimentos). (BRASIL, 2017).

O acesso as linhas de financiamentos são definidas pelo perfil produtivo que cada agricultor possui, e as linhas de financiamento tem suas especificidades como taxas de juros, prazo de carência entre outras. Para ter acesso ao crédito do Pronaf, os camponeses têm que possuir a Declaração de Aptidão ao Pronaf (DAP), que é um documento de identificação do agricultor familiar, no qual a unidade familiar cadastrada passa a ter direito de acessar políticas públicas. $O$ agricultor familiar que se enquadra nas normas vigentes deve procurar uma entidade credenciada Secretaria de Agricultura Familiar e Cooperativismo, órgão subordinado ao Ministério da Agricultura Pecuária e Abastecimento (MAPA) que tem o poder de emitir este documento. Com o documento em mãos, o agricultor familiar passa a poder acessar diversos programas do governo federal, como financiamento com baixas taxas de juros, participar do Programa de Aquisição de Alimentos (PAA), Programa Garantia Safra, dentre outros. (BRASIL, 2019).

Tivemos ao longo da história, outra política pública voltada, especificamente, aos camponeses-assentados, o Programa Lumiar, criado em 1997 para assessorar as famílias assentadas pelo INCRA. O Lumiar propunha a construção de um sistema de cogestão, inserindo as famílias nas diferentes fases de produção, a partir da imersão de vários técnicos da área social e agronômica. Foi concebido como um programa emergencial para suprir a demanda criada pelo aumento do número de assentamentos em todo o país e a pressão para que este tivesse assessoria técnica. No momento em que foi criado o Projeto Lumiar, o governo foi implementando a pauta gerada pelos movimentos, no seu final, era o governo que tomava a iniciativa do processo e, através de argumentos, como excesso de gastos e denúncias de má gestão dos recursos, vai minando os instrumentos de avanço da reforma agrária, entre eles, o Projeto Lumiar (SILVA; ARAUJO, 2008).

Outra grande conquista para agricultura camponesa foi a criação do Ministério do Desenvolvimento Agrário (MDA) do Brasil. Fundado em 25 de novembro de 1999 pela medida provisória $\mathrm{n}^{\circ}$ 1.911-12 e sua última estrutura regimental foi definida pelo decreto no 7.255 de 4 de agosto de 2010. Para pensar, criar e coordenar as políticas públicas para a pequena agricultura. (BRASIL, 2019).

Houve uma conquista na parte da legislação, também, para a agricultura camponesa, foi a Lei 11.326, de 2006, conhecida como "Lei da Agricultura Familiar", que objetivou definir o público e os beneficiários da política nacional da agricultura familiar e qualificar os empreendimentos familiares rurais. Neste documento, considera-se agricultor familiar e empreendedor familiar rural aquele que pratica atividades no meio rural, e que se encaixe em tais requisitos, como: mão de obra familiar, área igual ou menor a 4 módulos fiscais, renda familiar oriunda de sua propriedade rural, entre outros requisitos (BRASIL, 2006).

Diante deste breve histórico pode-se concluir que o Pronaf, com todas as suas contradições, foi uma conquista advinda da luta das famílias camponeses na busca por políticas públicas de crédito rural, que pudesse viabilizar a sua produção, aumentando a renda familiar, melhorando a qualidade de vida dos camponeses e 
CONSIDERAÇÕES ACERCA DO PROGRAMA NACIONAL DE FORTALECIMENTO DA AGRICULTURA FAMILIAR (PRONAF) NO PROJETO DE ASSENTAMENTO SANTA ROSA EM ITAQUIRAÍ - MS

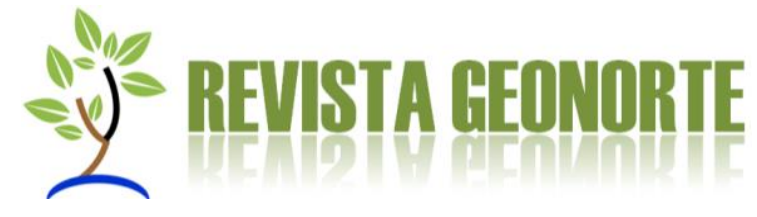

auxiliando no processo de resistência para permanecer no campo. Sendo assim, as lutas camponesas no Brasil, por meio de movimentos sociais e sindicais, por uma nova proposta de desenvolvimento no campo, levaram o Estado, impulsionado pela pressão desses movimentos, a criar programas para desenvolver a agricultura familiar/camponesa.

\section{AGRICULTURA CAMPONESA VERSUS AGRONEGÓCIO}

Apesar de na análise sobre as políticas públicas (neste caso, o Pronaf), o agricultor familiar ser o conceito utilizado, defendemos o conceito de agricultura camponesa porque "a discussão teórica da agricultura familiar tem construído a compreensão e a percepção de que o camponês representa o velho, o arcaico e o atraso, enquanto o agricultor familiar representa o novo, o moderno, o progresso". (FERNANDES, 2012, p.07).

Nesta perspectiva paradigmática, temos dois modelos distintos de agricultura no Brasil. O primeiro é a agricultura camponesa, uma vez que as famílias são proprietárias das terras e dos recursos naturais que elas necessitam para desempenhar suas atividades produtivas e da força de trabalho (COSTA, 2000).

As famílias camponesas estabeleceram uma especificidade que Ihes é própria, seja em relação ao modo de produzir e à vida comunitária, seja na forma de tratar a natureza. A produção camponesa, por terem como centralidade a reprodução social dos seus trabalhadores diretos, que são os próprios membros da família, apresentam uma racionalidade distinta daquela das empresas capitalistas, baseada no assalariamento. Também, o modo camponês de fazer agricultura não está separado do modo de viver da família, uma vez que é preciso considerar que eles participam de uma completa interação, compartilhando saberes e experiências de produção, ou trocando informações com vizinhos ou parentes (CARVALHO; COSTA, 2012).

O segundo modelo é o agronegócio. O termo foi criado para expressar as relações econômicas, entre o setor agropecuário e aqueles situados na esfera industrial, comercial e de serviços. Em seu início, tratava-se de criar uma proposta de análise sistêmica que superasse os limites da abordagem setorial então predominante, elevando o processo de modernização e industrialização da agricultura. Hoje, observa- se, tanto sua tendência em controlar áreas cada vez mais extensas de terras do país, como também, o predomínio de empresas multinacionais. Este processo hegemônico dos grandes grupos empresariais controlam a produção, armazenamento e a venda dos produtos diretamente para o mercado internacional, sem nenhum, ou pouquíssimo, benefícios para o Brasil. A lógica da expansão do agronegócio no Brasil está ligada à disponibilidade de terras. Assim, para os empresários do setor, além das terras em produção, é necessário ter um estoque disponível para a expansão. O que provoca um aumento dos preços das terras, tanto em áreas onde o agronegócio já se implantou, quanto nas áreas que podem possibilitar o crescimento da produção (LEITE; MEDEIROS, 2012).

Embora tenha havido uma redução de mão de obra no setor agrícola, o emprego do trabalho assalariado em atividades braçais está longe de desaparecer. Temos os trabalhadores permanentes e temporários, tanto àqueles com direitos trabalhistas assegurados, como os que vivem à margem desses direitos. A expansão do 
CONSIDERAÇÕES ACERCA DO PROGRAMA NACIONAL DE FORTALECIMENTO DA AGRICULTURA FAMILIAR (PRONAF) NO PROJETO DE ASSENTAMENTO SANTA ROSA EM ITAQUIRAÍ - MS

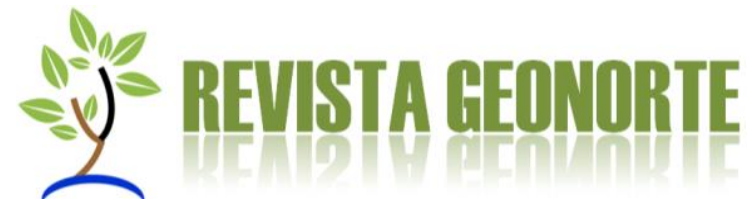

agronegócio tem levado tanto às formas degradantes de trabalho, como à destruição ambiental, onde as matas nativas estão sendo derrubadas. Estes processos de superexploração do trabalho foram denunciados por entidades como a Organização Internacional do Trabalho (OIT) e a Comissão Pastoral da Terra (CPT) como sendo condições análogas à escravidão (LEITE; MEDEIROS, 2012).

Assim, surgem as críticas ao modelo do agronegócio, se contrapondo ao modelo da agricultura camponesa, que valoriza a agricultura de trabalho familiar, a produção de alimentos para o autoconsumo e uma relação de equilíbrio ambiental. Nesta perspectiva partimos da ideia de que a sobrevivência dos povos do campo e a reprodução das suas relações de trabalho com a terra é de extrema importância, haja vista que esta é uma condição primordial para a manutenção da existência da nossa sócio-biodiversidade, principalmente porque esses povos possuem uma relação com a natureza de respeito e preservação, e esta é uma dinâmica inerente à sua sobrevivência que se contrapõe ao agronegócio que enxerga a natureza como fonte de exploração para o lucro (CAMACHO, 2016).

Desta maneira, podemos enfatizar que a agricultura camponesa está sempre em contraposição ao agronegócio e sua produção de monocultura em larga escala, como assinala Camacho:

Podemos sintetizar as marcantes diferenças entre a agricultura camponesa e o agronegócio por meio das diferenças existentes entre o campo diversificado e ambientalmente saudável onde predomina a agricultura camponesa e o campo vazio e ambientalmente em risco onde predomina o agronegócio. Todavia, não podemos generalizar as observações acerca da agricultura camponesa e, consequentemente seu antagonismo com relação ao agronegócio, tratando essa problemática a partir de uma análise idealista e simplista, pois a própria lógica de mercado impõe a produção de escala, até para que ela chegue ao mercado. Por isso, não é raro ver camponeses ocupados com uma única atividade comercial. Confirmando a necessidade de luta contra o capital. (CAMACHO, 2016, p.09).

\section{HISTÓRIA DE FORMAÇÃO DO ASSENTAMENTO SANTA ROSA, MUNICÍPIO DE ITAQUIRAÍ - MS}

O município de Itaquiraí (figura 1) está localizado a 404 quilômetros da capital, Campo Grande, possui, de acordo com dados do Censo Demográfico do Instituto - (IBGE, 2010), cerca de 18.614 habitantes e deste percentual 11.014 são residentes na área rural e apenas 7.600 são moradores da área urbana. De acordo com dados do Censo Agropecuário 2017 o município tem 2.817, estabelecimento agropecuários e 2.723 são estabelecimentos que estão na faixa de até 50 hectares.

A economia do município é movida pela produção agropecuária. No setor animal, a criação de gado de corte, galináceos de corte e bicho da seda tem impulsionado a geração de renda. Já no setor agrícola, as receitas são advindas no plantio de lavouras temporárias como soja, milho, mandioca e cana-de-açúcar que ocupam juntas $96 \%$ das terras.

Atualmente há, no município, 12 assentamentos de reforma agrária e contabiliza 2.630 famílias assentadas (tabela1). O primeiro assentamento teve seu início no ano de 
CONSIDERAÇÕES ACERCA DO PROGRAMA NACIONAL DE FORTALECIMENTO DA AGRICULTURA FAMILIAR (PRONAF) NO PROJETO DE ASSENTAMENTO SANTA ROSA EM ITAQUIRAÍ - MS

1989, com a desapropriação fazenda Itasul para o assentamento de 617 famílias. A partir das lutas dos movimentos sociais que atuavam na região nos anos de 1996 e 1997 foram responsáveis pelas desapropriações das fazendas Sul Bonito, Jatobá e Zé Mano e foram criados os assentamentos Sul Bonito, Santa Rosa ${ }^{3}$ e Guaçu, totalizado 694 famílias. A seguir na figura 1, veja o mapa da localização dos assentamentos no município de Itaquirai/MS.

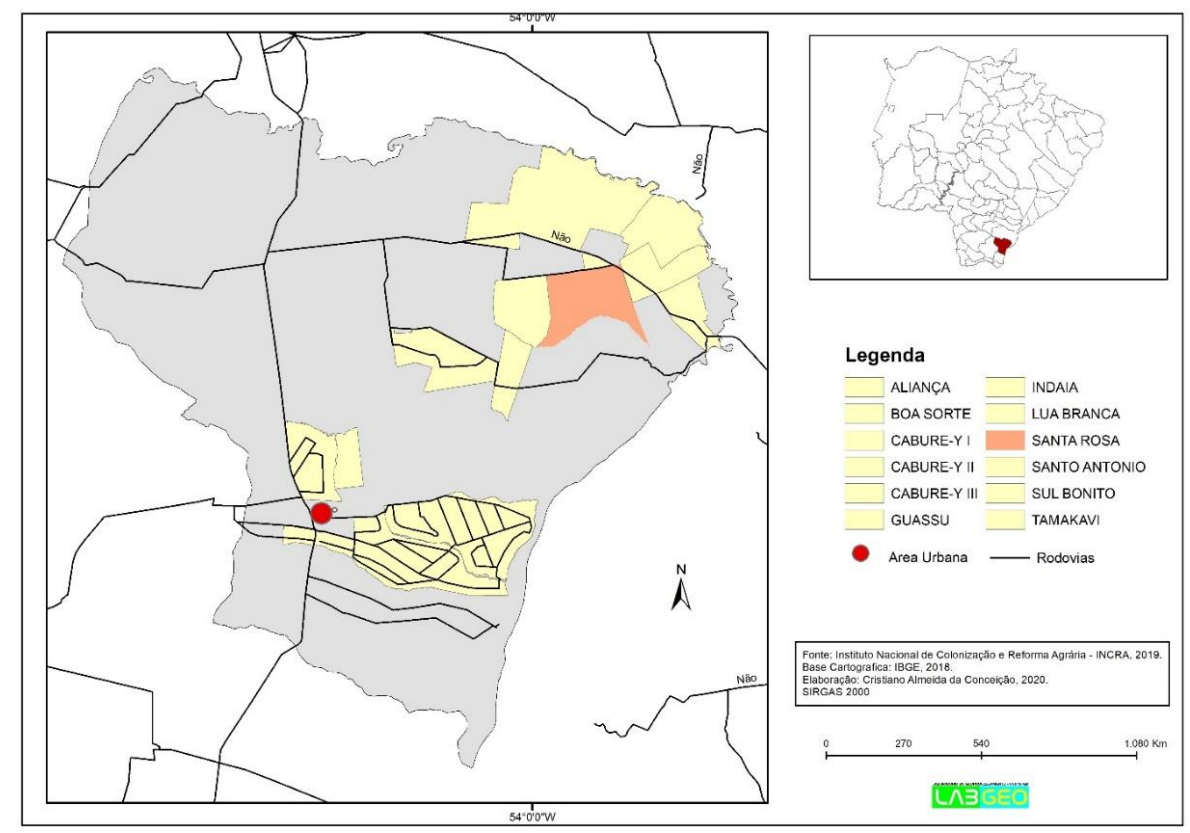

Figura 1 - Mapa de localização dos assentamentos no município de Itaquiraí - MS. Fonte: Autores.

Tabela 1. Relação de assentamentos rurais pelo Programa Nacional de Reforma Agrária Itaquiraí - MS

\begin{tabular}{cccc}
\hline Denominação do Projeto & Ano & N.o de Famílias & Área (ha) \\
\hline Indaiá & 1989 & 617 & $7.340,6719$ \\
Sul Bonito & 1996 & 421 & $6.375,9385$ \\
Santa Rosa & 1997 & 141 & $4.048,1606$ \\
Guaçu & 1997 & 132 & $2.678,3434$ \\
Tamakavi & 1998 & 120 & $3.383,567$ \\
Boa Sorte & 1998 & 64 & $1.597,2011$ \\
Aliança & 2000 & 37 & 1162,4674 \\
Lua Branca & 2001 & 123 & 2608,5653 \\
Santo Antonio & 2007 & 531 & $9.627,8274$ \\
Itaquiraí & 2007 & 208 & $3.232,9883$ \\
Foz Do Rio Amambai & 2007 & 137 & $2.210,021$ \\
Caburéy & 2007 & 99 & $1.848,2303$ \\
Total & & & \\
\hline
\end{tabular}

Fonte: Organizado por: INCRA, 2018. Relatório de Assentamento. Superintendência Regional Mato Grosso do Sul.

${ }^{3}$ O Assentamento Santa Rosa, objeto de estudo deste artigo, será discutido mais adiante.

REVISTA GEONORTE, V.11, N.38, p.200-223, 2020.

DOI: 10.21170/geonorte.2020.V.11.N.38.200.223

(ISSN 2237 - 1419) 
CONSIDERAÇÕES ACERCA DO PROGRAMA NACIONAL DE FORTALECIMENTO DA AGRICULTURA FAMILIAR (PRONAF) NO PROJETO DE ASSENTAMENTO SANTA ROSA EM ITAQUIRAÍ - MS

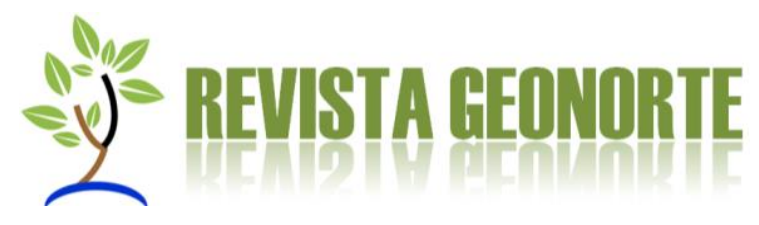

A origem das famílias que estão assentadas no assentamento Santa Rosa, objeto do nosso estudo, se deu com a formação do Acampamento 408 de Março, que recebeu esse nome por ser a data de sua fundação. Esse acampamento se localizou próximo a Fazenda Mestiça, as margens da BR-163. O Acampamento 08 de Março era composto por 2.064 famílias oriundas de diversos estados brasileiros, cidades do estado de Mato Grosso do Sul e de brasiguaios que retornaram do Paraguai depois de um longo período vivendo em terras guaranis.

Durante o processo de luta pela terra as famílias do acampamento 8 de Março ocuparam a Fazenda Santo Antônio, como forma de reenvidicar a execução da reforma agrária, mas, logo foram obrigados a deixarem a fazenda por ordem judicial, a desocupá-la, e retornando assim novamente para as margens da BR-163. Neste retorno do acampamento para a BR 163 as famílias permanceram por um período de um ano e seis meses até acontecer a desapropriação, corte dos lotes e sorteio das terras na fazenda Santa Rosa. No período de acampamento, diversas famílias passaram por várias dificuldades não somente econômicas, mas também sociais, como falta de moradia digna, alimentação adequada, segurança e respeito aos seus direitos. A seguir é possível ver na foto (figura 2) o Acampamento 08 de Março, na qual, se podem perceber as precárias condições de moradia das famílias que ali residiam na ocupação da fazenda Santo Antonio.

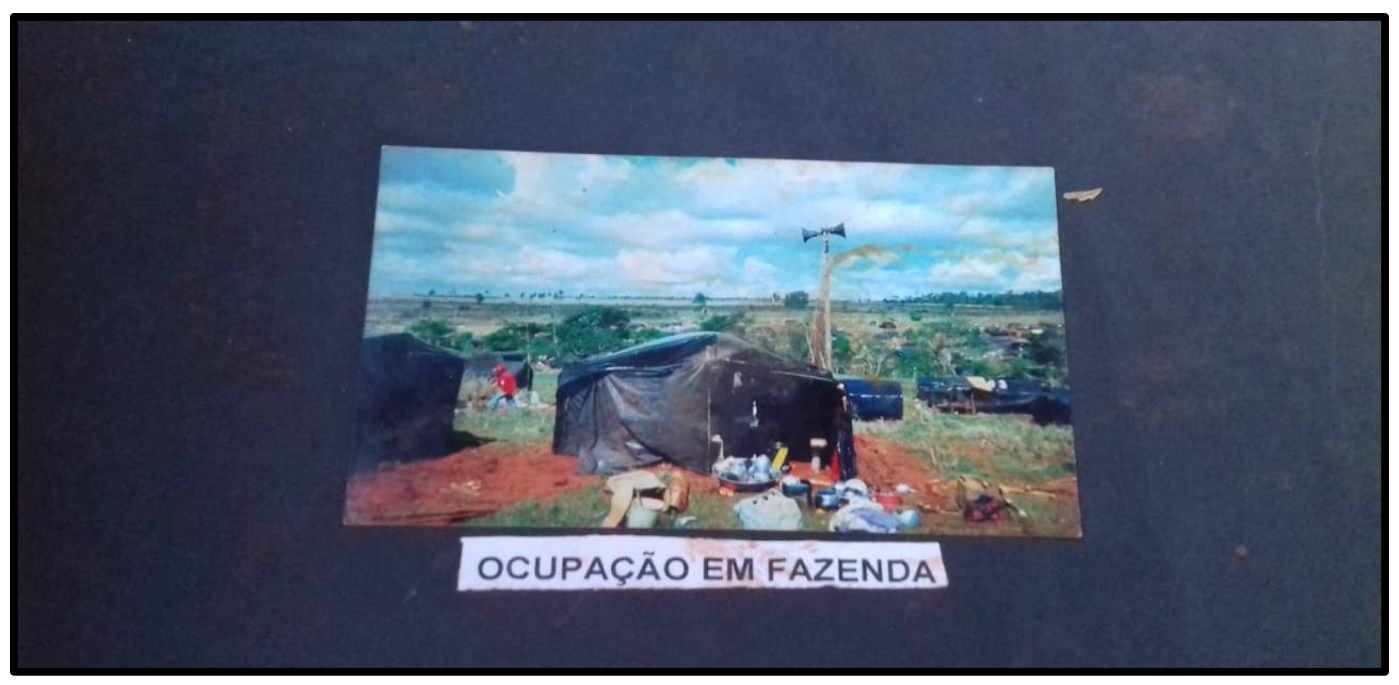

Figura 2 - Acampamento 8 de Março. Fonte: Acervo pessoal do assentado João.

No ano de 1998, as famílias assentadas deram o nome desta terra conquistada de assentamento José Milton ${ }^{5}$, todavia o INCRA manteve o nome antigo da fazenda de Santa Rosa como nome do assentamento. O assentamento é composto por 141 lotes, e cada lote tem em média de 15 hectares, parte dos lotes do assentamento foram

\footnotetext{
4 "Acampamento é um espaço de luta e resistência. É a materialização de uma ação coletiva que torna pública a intencionalidade de reivindicar o direito a terra para produção e moradia". (FERNANDES, 2012, p.23).

${ }^{5}$ Coordenador e militante do MST, assassinado em 1998, por "jagunços" de fazendeiros.
}

REVISTA GEONORTE, V.11, N.38, p.200-223, 2020.

DOI: 10.21170/geonorte.2020.V.11.N.38.200.223

(ISSN 2237 - 1419) 
CONSIDERAÇÕES ACERCA DO PROGRAMA NACIONAL DE FORTALECIMENTO DA AGRICULTURA FAMILIAR (PRONAF) NO PROJETO DE ASSENTAMENTO SANTA ROSA EM ITAQUIRAÍ - MS

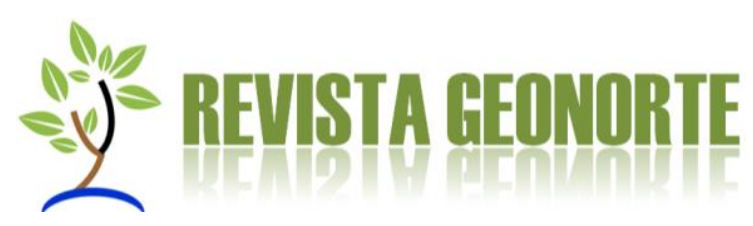

loteados em sistema de agrovila ${ }^{6}$ dando origem a seis núcleos. A infraestrutura para o uso comum dos assentados é composta um posto de saúde; uma quadra de esportes coberta, que antes pertencia a Escola Municipal Santa Rosa e que atualmente foi transferida para o assentamento Santo Antonio; três igrejas católicas e quatro igrejas evangélicas; além de rede de distribuição de água e energia elétrica em todos os sítios. Ainda há no assentamento duas associações de produtores rurais e elas têm à disposição aos associados os seguintes equipamentos: um trator BM110, uma grade intermediária (aradora), um subsolador (arado), "afofador" de mandioca, uma "carretinha" (reboque) um carro (fiorino) - para carregar mercadorias -, uma "ensiladeira" para trator (máquina para picar biomassa) e uma "calcariadeira" (equipamento de aplicação do calcário). A seguir na figura 2 temos algumas imagens dos produtos e produções da associação 8 de março.

Figura A-Trator

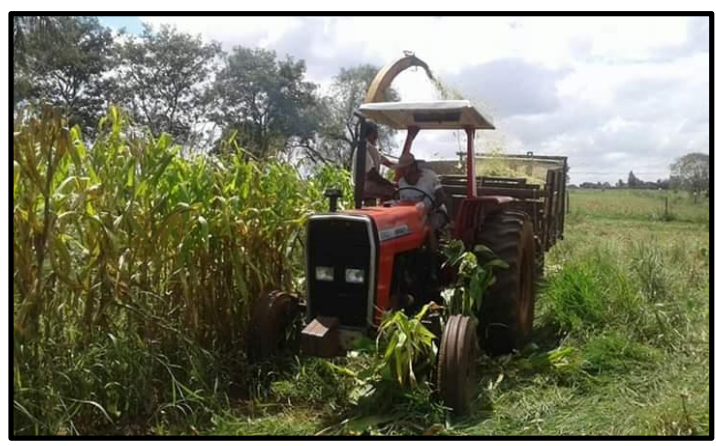

Figura C - Carro Fiorino

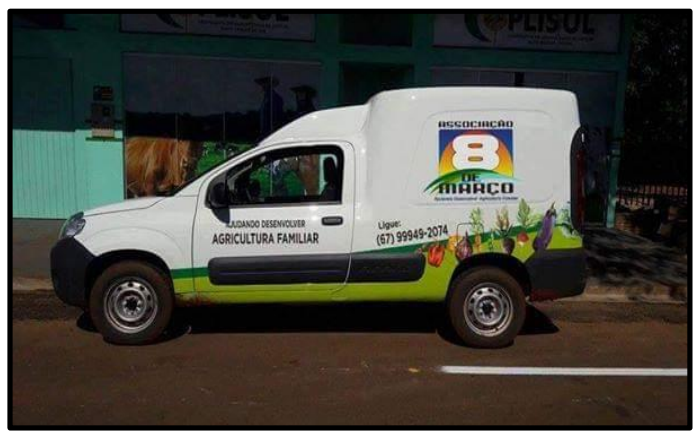

Figura B- Colheita

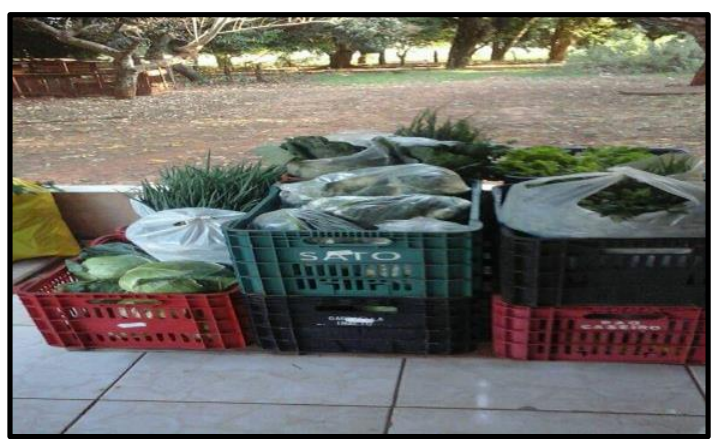

Figura D- Plantação de Cebola

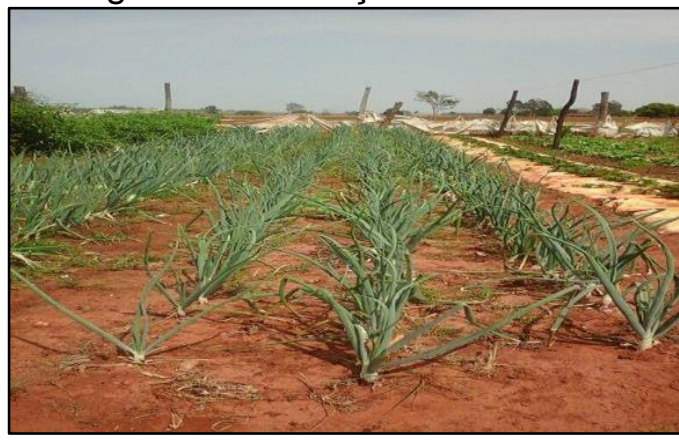

Figura 3 - Produtos e produções da Associação 8 de março.

Fonte: Associação 8 de março (2019).

\section{O PROGRAMA NACIONAL DE FORTALECIMENTO DA AGRICULTURA FAMILIAR (PRONAF) NO ASSENTAMENTO SANTA ROSA}

Este estudo foi realizado no Assentamento Santa Rosa no ano 2019. Utilizou-se para a pesquisa um questionário estruturado que foi aplicado à 20 agricultores.

\footnotetext{
${ }^{6}$ Núcleo onde são disponibilizados infraestrutura básica, com instalações de igrejas, escolas ou postos de saúde. Também criada para o convívio em comunidade, facilitando os meios de produção.
}

REVISTA GEONORTE, V.11, N.38, p.200-223, 2020.

(ISSN 2237 - 1419) 
CONSIDERAÇÕES ACERCA DO PROGRAMA NACIONAL DE FORTALECIMENTO DA AGRICULTURA FAMILIAR (PRONAF) NO PROJETO DE ASSENTAMENTO SANTA ROSA EM ITAQUIRAÍ - MS

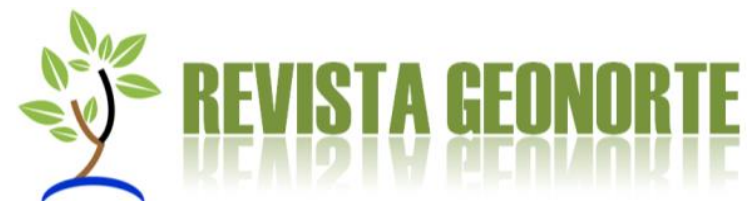

Foi identificado o predomínio da figura masculina como titular do lote, o qual possui uma idade superior aos 40 anos de idade. Os assentados, em sua maioria, são oriundos do próprio estado de Mato Grosso do Sul, dos municípios de Vicentina, Jatei, Dourados, Paranhos, Deodápolis, Itaquiraí, Angélica, Naviraí e Eldorado. Há também um número considerável de famílias oriundas do estado do Paraná, dos municípios de Guaíra, Corbélia, Mercedes, Curitiba, Andirá, Icaraíma e Loanda. Além disso, há no assentamento famílias brasiguaias de Katuete - PY.

Os entrevistados ao serem indagados sobre seu último lugar de morada antes de entrarem na luta pela terra, pode-se observar uma predominância na ligação com o meio rural, ou seja, na condição de arrendatário ou de funcionário de fazenda. Em relação ao período de estar acampado até a conquista da terra, o intervalo foi entre oito meses a nove anos de acampados. No entanto, alguns entrevistados ao reportar ao período e na condição de acampados afirmaram que se mantiveram firmes nesse tempo, pois era o sonho de adquirir um "pedaço" de terra, para poder plantar e dar uma qualidade de vida melhor para a família e morar no que é seu.

Das 20 famílias entrevistadas, pode se notar a queda no número de pessoas residentes no início do assentamento no ano de 1998 e no período da pesquisa (fevereiro de 2019). No início do assentamento cada família continha em média quatro pessoas no sítio (com algumas exceções de até nove pessoas), e nos dias atuais a média é de três pessoas.

Mesmo ocorrendo a redução no número de pessoas residindo por sítio, o percentual de famílias moradoras consideradas pioneiras é de $60 \%$ no assentamento Santa Rosa. Já as famílias residentes há menos tempo no assentamento, muitos deles são parentes de pessoas do próprio Santa Rosa e adquiriram o direito de outro morador (figura 4).

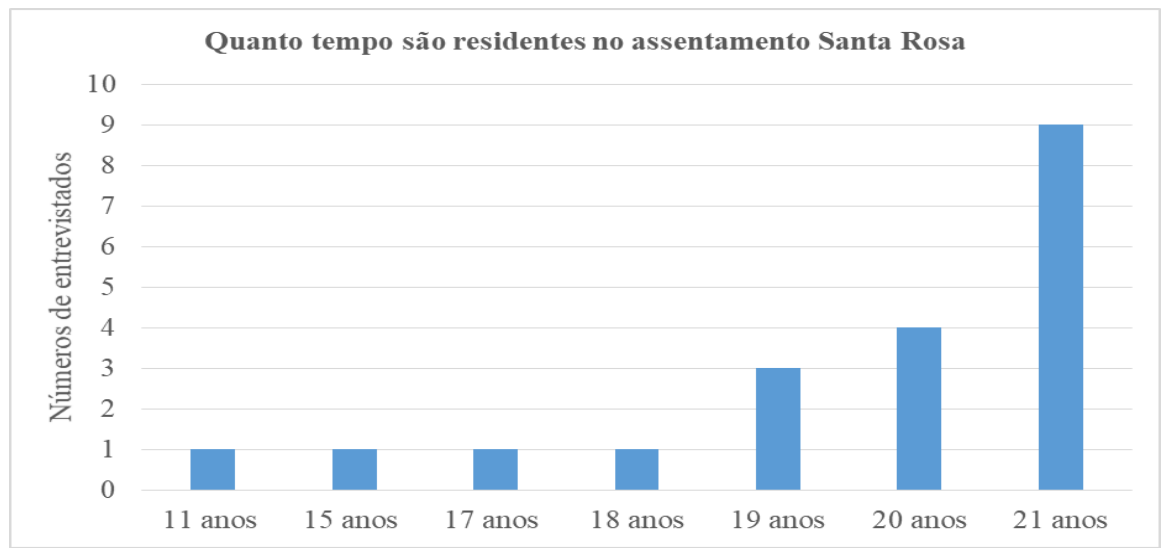

Figura 4 - Tempo de residência no assentamento. Fonte: Pesquisa de campo (2019).

Embora, o assentamento Santa Rosa até o ano de 2018, possuisse o ensimo fundamental, a escola foi fechada pela secretaria de educação do município alegando falta de recursos financeiros. A pesquisa, constatou uma baixa escolaridade entre a população amostrada, uma vez que parte dos entrevistados não chegou a concluiu o ensino fundamental. Com relação a conclusão do ensino médio e superior é 
CONSIDERAÇÕES ACERCA DO PROGRAMA NACIONAL DE FORTALECIMENTO DA AGRICULTURA FAMILIAR (PRONAF) NO PROJETO DE ASSENTAMENTO SANTA ROSA EM ITAQUIRAÍ - MS

relativamente baixo entre os entrevistados, como pode ser observado na figura 5. Ressaltando que a baixa escolaridade é em maior número entre os titulares dos lotes.

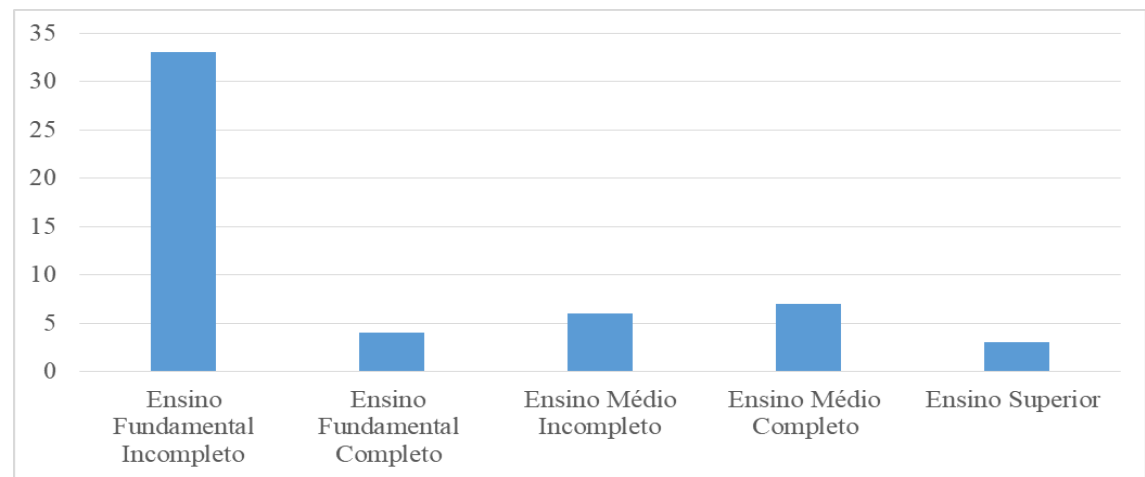

Figura 5 - Escolarização dos entrevistados. Fonte: Pesquisa de campo (2019).

Dos moradores entrevistados, $80 \%$ deles trabalham somente no sítio e os outros $20 \%$ dividem parte de sua jornada de trabalhos desempenhando outras funções como: funcionários públicos, diaristas ou trabalham em fazendas existentes próximo ao assentamento. No entanto, foi perguntado se há a contratação de mão-de-obra temporária e cerca de $90 \%$ dos agricultores responderam que a não há necessidade de contratação de mão de obra temporário, e 10\% que sinalizaram a necessidade de um auxílio em algumas épocas da produção, fazendo a contratação para desempenhar atividades específicas.

Dentre as atividades produtivas desenvolvidas nos sítios, a pecuária de leite é a principal e a que representa a maior fonte de renda as famílias. Em relação as plantações, as culturas estão concentradas basicamente nos cultivos de mandioca, melancia, milho, feijão, hortaliças e bananas, e o tamanho das áreas cultivadas variam de 0,5 hectares a 9 hectares (figura 6). Já na criação de animais, os bovinos representam cerca de $36 \%$ da produção, enquanto a avicultura e os suínos $30 \%$ e a apicultura e ovinos aparecem em apenas $2 \%$ dos entrevistados.

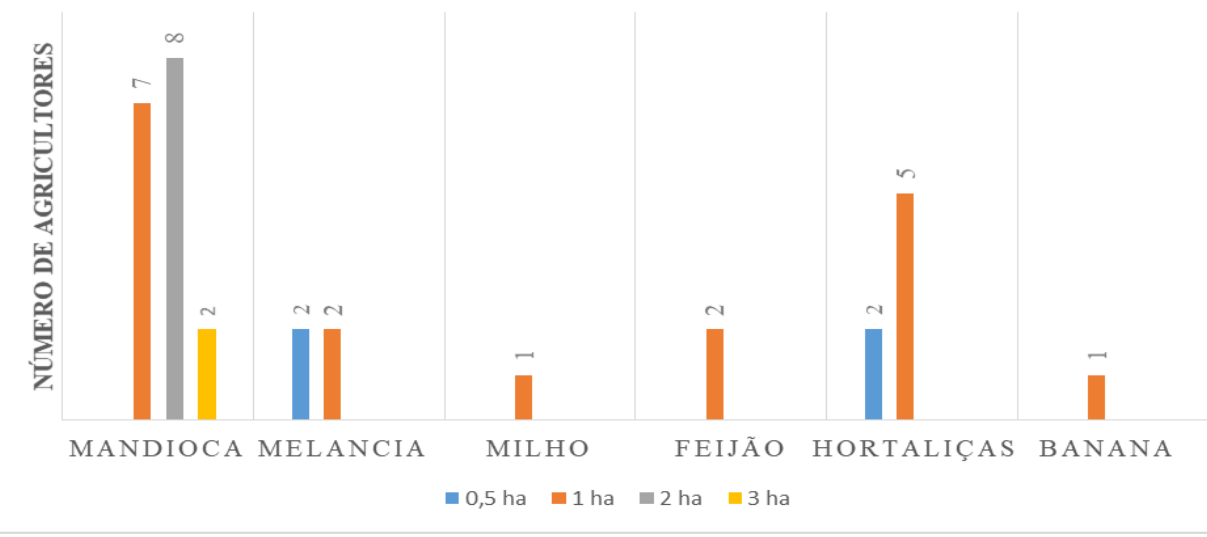

Figura 6- Plantações dos assentados e os números de hectares respectivamente.

Fonte: Pesquisa de campo (2019). 
CONSIDERAÇÕES ACERCA DO PROGRAMA NACIONAL DE FORTALECIMENTO DA AGRICULTURA FAMILIAR (PRONAF) NO PROJETO DE ASSENTAMENTO SANTA ROSA EM ITAQUIRAÍ - MS

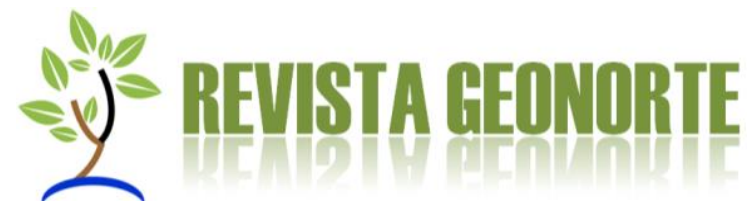

Com relação aos canais de comercialização foram identificados quatro espaços de comércio acessados pelos entrevistados. Nestes quatros canais de comercialização as vendas aos atravessadores (intermediário entre o produtor e o varejista) corresponde a $55 \%$, a comercialização para os supermercados (local de compra e venda de mercadorias) equivale a $24 \%$, o Programa Nacional de Alimentação Escolar (PNAE) chega a $15 \%$ e por ultimo o Programa de Aquisição de Alimentos (PAA) apenas $6 \%$ dos entrevistados.

Perguntados sobre as técnicas de cultivo, os entrevistados demonstraram grande variedade entre si, pela grande quantidade na produção leiteira, a ordenha mecânica vem crescendo entre os assentados. Em suas produções, a utilização de calcário, adubo orgânico, adubo químico ou adubação verde, estão sendo muito utilizados. Em suas formas de plantações, a rotação e o consórcio de culturas, também foi destacado, como pode ser analisado na figura 7.

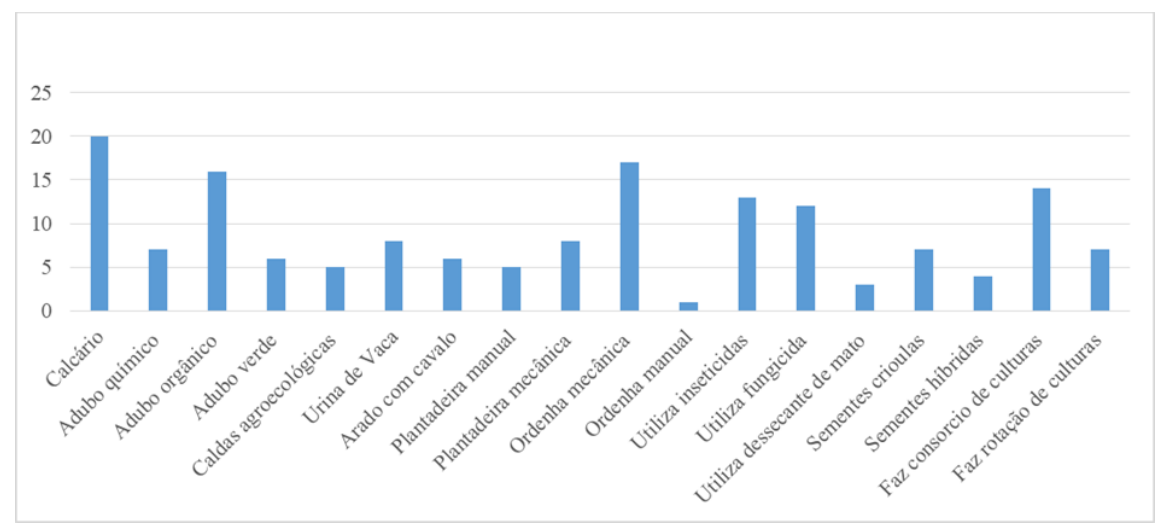

Figura 7 - Meios de produção dos entrevistados.

Fonte: Pesquisa de campo (2019).

Quanto a participação em coletivos, a maioria participa de algum movimento social (34\%), associação de agricultores (33\%), associação cooperativa (14\%) e apenas $19 \%$ não está associado ou pertencente à alguma entidade de classe.

De acordo com um representante da Agraer ${ }^{7}$, atualmente no município de Itaquirai, só está sendo acessado a linha de crédito do Pronaf, o qual a linha mais acessada é o Pronaf mais alimento nos assentamentos do município. Tendo em média 120 custeio por ano, que se destina a financiar atividades agropecuárias e não agropecuárias, de beneficiamento ou de industrialização da produção própria ou de terceiros enquadrados no Pronaf, de acordo com projetos específicos ou propostas de financiamento. E o financiamento que varia de 80 a 100 por ano, de acordo com a linha de financiamento expedida. Onde se percebe uma queda, pois há dez anos os números eram de 250 a 300 custeios, 180 a 200 financiamentos.

7 Tem por missão definir as políticas e a coordenação das atividades de assistência técnica, extensão rural, pesquisa e outros serviços ligados ao desenvolvimento e ao aprimoramento, da agricultura e pecuária, destinadas aos produtores rurais, com prioridade para os agricultores familiares, agricultores tradicionais, assentados, indígenas, quilombolas, pescadores e aquicultores do Mato Grosso do Sul. (AGRAER, 2019). 
CONSIDERAÇÕES ACERCA DO PROGRAMA NACIONAL DE FORTALECIMENTO DA AGRICULTURA FAMILIAR (PRONAF) NO PROJETO DE ASSENTAMENTO SANTA ROSA EM ITAQUIRAÍ - MS

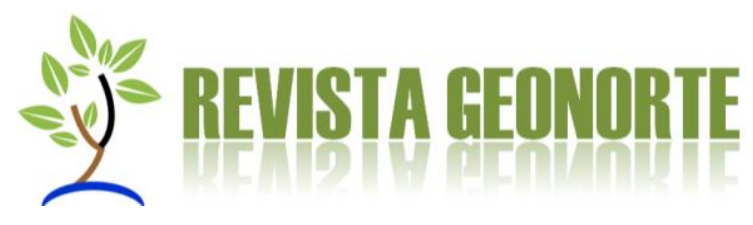

No assentamento Santa Rosa, o Programa Nacional de Fortalecimento da Agricultura Familiar (Pronaf) foi acessado pela primeira vez no ano de 2004 (tabela 2), sendo no ano de 2012 o maior número de contratos. Dos valores recebidos em média, há uma variação no ano e na linha de acesso, onde é de $R \$ 1.500,00$ do valor que é investido na terra, fazendo a adequação e correção do solo, recuperando pastagens entre outras.

Tabela 2- Ano do último financiamento do Pronaf no assentamento Santa Rosa

\begin{tabular}{|l|l|l|}
\hline Ano & Número de famílias & Valor acessados \\
\hline 2004 & 1 & $\mathrm{R} \$ 12.800,00$ \\
\hline 2010 & 1 & $\mathrm{R} \$ 21.000,00$ \\
\hline 2012 & 7 & $\mathrm{R} \$ 23.000,00$ \\
\hline 2013 & 1 & $\mathrm{R} \$ 21.000,00$ \\
\hline 2014 & 1 & $\mathrm{R} \$ 12.800,00$ \\
\hline 2015 & 3 & $\mathrm{R} \$ 71.000,00$ \\
\hline 2016 & 1 & $\mathrm{R} \$ 49.000,00$ \\
\hline 2018 & 1 & $\mathrm{R} \$ 10.000,00$ \\
\hline 2019 & 1 & $\mathrm{R} \$ 54.000$ \\
\hline
\end{tabular}

Fonte: Pesquisa de campo (2019)

Do total de 20 entrevistados, apenas 1 não obteve financiamento pelo Pronaf, financiado pelo Banco do Brasil-Pronaf. Os que fizeram o financiamento, teve sua finalidade no investimento, em sua maioria, na produção de bovino de corte e leite, seguidos das produções de milho, feijão, mandioca, construção de cercas e benfeitorias no lote, compra de insumos e pagamentos de serviços (figura 8).

Ao serem indagados se ao acessar as linhas de financiamentos eles obtiveram êxitos cerca de $68 \%$ disseram que aumentou a sua produção, $21 \%$ permaneceu no mesmo desempenho e $11 \%$ tiveram queda da produção depois de acessar o Pronaf.

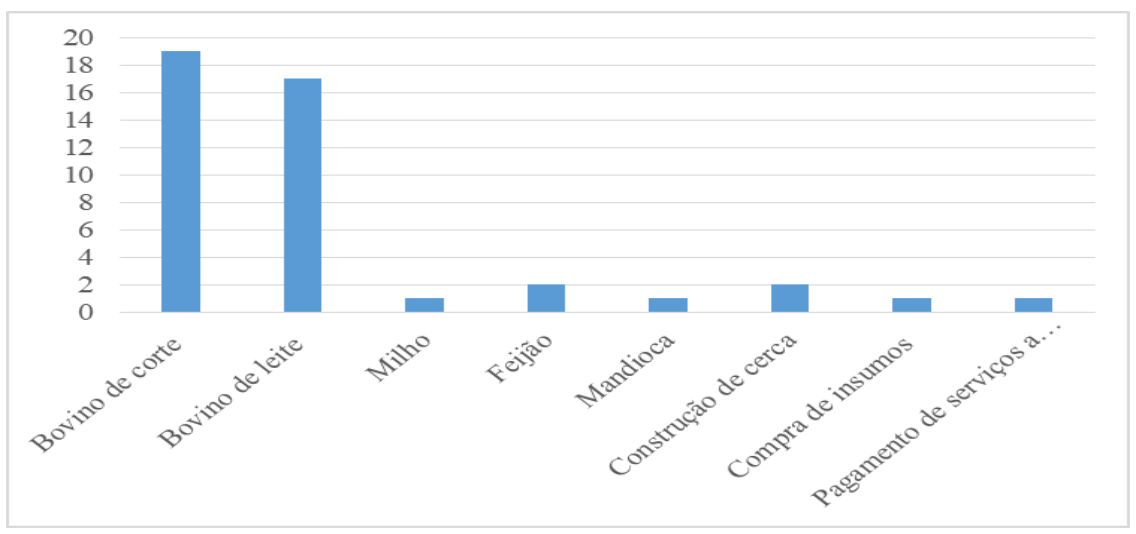

Figura 8 - Utilização do Pronaf nas propriedades. Fonte: Trabalho de Campo (2019).

Com relação a liberação do crédito, vários entrevistados reclamaram da demora na liberação dos recursos, bem como a burocracia e a falta de interesse da Agraer em fazer a vistoria. Já em relação a assistência técnica e extensão rural os entrevistados relataram que não houve acompanhamento técnico e contínuo para os camponeses 
CONSIDERAÇÕES ACERCA DO PROGRAMA NACIONAL DE FORTALECIMENTO DA AGRICULTURA FAMILIAR (PRONAF) NO PROJETO DE ASSENTAMENTO SANTA ROSA EM ITAQUIRAÍ - MS

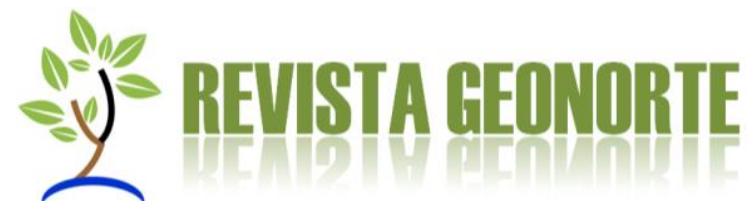

que obtiveram o crédito do Pronaf e ainda destacaram que a assistência técnica ocorreu somente na elaboração do projeto.

Em entrevista com representante da Agraer no escritório de Itaquiraí ${ }^{8}$, foi indagado como a instituição tem se portado diante das críticas recebida em relação a qualidade da assistência técnica e extensão rural. De acordo com o entrevistado, "a baixa qualidade na assistência técnica é devido a falta de técnicos presentes no município, pois o escritório conta com apenas 6 técnicos para atender mais de 3000 agricultores, e nós procuramos atender mais aqueles que procuram o escritório e solicita acompanhamento técnico".

No que se refere a quitação do financiamento, foi constatado que apenas $16 \%$ dos entrevistados quitaram o financiamento. Já em relação aos motivos da inadimplência alta na quitação dos financiamentos pode estar relacionado com a falta de orientação técnica de como deve ser investindo. Há casos de que o dinheiro do financiamento foi utilizado para outros fins e o retorno do investimento não veio e, assim, acarretou o endividamento.

Entretanto, há casos de endividamento de agricultores que foram avalistas de outros agricultores, e a não quitação do crédito levaram diversos deles a inadimplência. Como é exposto nos relatos dos entrevistados; "eu não soube investir o dinheiro, também não tive retorno, ai eu não tive como pagar e nem meu avalista conseguiu, e tô devendo até hoje". Se obteve outras respostas como: "desviei o dinheiro para outros fins"; "estou pagando"; avaliei para o vizinho e ele não pagou o financiamento". O aval cruzado como um dos elementos para a liberalização do financiamento tem demostrado ser uma prática peversa, pois o "bom pagador" fica em muitos casos refém dos maus investidores ou pagador.

No que diz respeito aos motivos da inadimplência em relação ao financiamento Pronaf, o representante da Agraer considera que a alta a taxa de inadimplência do Pronaf no município, não se sabe qual é a real causa para a inadimplência, mas destaca que possa ser pela falta de conhecimento técnico em investimento por parte do pequeno agricultor.

Sobre seus sonhos de vida, os camponeses buscam uma vida tranquila, permanecer e produzir no campo, se estabilizar economicamente para garantir um futuro de qualidade para seus filhos. Como um dos assentados colocou,

\section{[...] permanecer no campo e produzir mais, viabilizar a minha questão econômica para dar uma qualidade de vida aos meus filhos e poder dar de estudos a eles, ter mais auxílio do governo, ter uma vida tranquila no sítio, que nós, produtores rurais, sejam mais valorizados na agricultura familiar (assentado 21 anos).}

Sonham com o dia em que os camponeses-assentados serão valorizados com a garantia, além do financiamento para a produção, de seus direitos a saúde e educação. Mas, o que pode ser destacado é a quantidade de pessoas que sonham

\footnotetext{
${ }^{8}$ Agente de Desenvolvimento Rural, trabalha a cerca de 21 anos no município de Itaquirai/MS (Jul. 2019).
}

REVISTA GEONORTE, V.11, N.38, p.200-223, 2020.

DOI: 10.21170/geonorte.2020.V.11.N.38.200.223

(ISSN 2237 - 1419) 
CONSIDERAÇÕES ACERCA DO PROGRAMA NACIONAL DE FORTALECIMENTO DA AGRICULTURA FAMILIAR (PRONAF) NO PROJETO DE ASSENTAMENTO SANTA ROSA EM ITAQUIRAÍ - MS

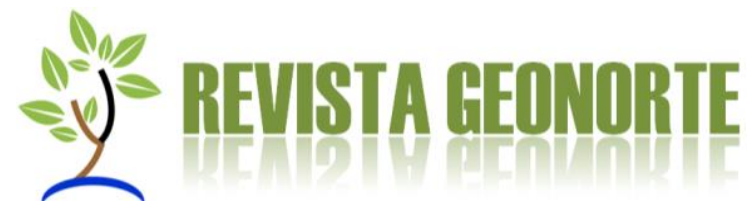

em pagar a sua dívida que fez com o financiamento do Pronaf, ressaltando, como é difícil viver com essa dívida e sem saber como irão pagar.

\section{CONSIDERAÇÕES FINAIS}

Dentre as estratégias produtivas adotadas pelas famílias no campo brasileiro, o acesso às políticas públicas voltadas para o fortalecimento da agricultura camponesa constitui-se de grande importância para a reprodução socioeconômica das famílias.

Como apresentado, o Pronaf foi a primeira política pública direcionada ao fortalecimento da agricultura camponesa que chegou aos assentados do assentamento Santa Rosa, de modo que a concessão do Pronaf representou um importante papel para o desenvolvimento da área de estudo, contribuindo para permanência no campo pela maioria das famílias.

No entanto, este é um caminho que apresenta muitos percalços devido à enorme quantidade de obstáculos que ainda precisam ser superados, os quais acabam transformando-se em limitações práticas do próprio programa, dentro da lógica de se alterarem os rumos atuais do desenvolvimento agrícola brasileiro.

Um dos limites do programa é a falta de apoio técnico para os beneficiários do Pronaf, no qual, muitos, sem orientações, acabam investindo de forma errada. O que se leva a mais um obstáculo, por não saber como aplicar, ou aplicando de forma errada, muitos camponeses, se veem hoje com dívidas altas no banco, sem saber como e de onde tirar recursos para pagar essa dívida.

Ainda que todos esses problemas sejam resolvidos, se não houver vontade política para a promoção e o fortalecimento da agricultura camponesa local, o programa dificilmente terá êxito em cumprir seu papel de fomentador. O alcance de seus objetivos depende, no entanto, de um acompanhamento e avaliação, que permitam garantir a sua efetiva e correta execução com uma análise de seus impactos.

\section{REFERÊNCIAS}

AGRAER. A Agência. Disponível em: <http://www.agraer.ms.gov.br/a-agencia/> . Acesso em: 10 jul. 2019.

BIANCHINI, V. Vinte anos do PRONAF, 1995-2015: avanços e desafios. Brasília: SAF/MDA, 2015.

BRASIL. Decreto $n^{\circ}$ 1.946, de 28 de junho de 1996. Disponível em: <http://www.planalto.gov.br/ccivil 03/decreto/D1946.htm>. Acesso em: 05 jul. 2019.

BRASIL. Lei $n^{\circ}$ 11,326, de 24 de julho de 2006. Disponível em: <http://www.planalto.gov.br/ccivil_03/_Ato2004-2006/2006/Lei/L11326.htm>. Acesso em: 05 jul. 2019. 
CONSIDERAÇÕES ACERCA DO PROGRAMA NACIONAL DE FORTALECIMENTO DA AGRICULTURA FAMILIAR (PRONAF) NO PROJETO DE ASSENTAMENTO SANTA ROSA EM ITAQUIRAÍ - MS

BRASIL. Secretaria da Agricultura Familiar e Cooperativismo. Disponível em: <http://www.mda.gov.br/sitemda/pagina/hist\%C3\%B3rico>. Acesso em: 06 jul. 2019.

BRASIL. Secretaria da Agricultura Familiar e Cooperativismo. Declaração de Aptidão ao Pronaf (DAP). Disponível em: <http://www.mda.gov.br/sitemda/saf/dap>. Acesso em: 06 jul. 2019.

BRASIL. Secretaria da Agricultura Familiar e Cooperativismo. Plano Safra da Agricultura Familiar 2017-2020. Disponível em: <http://www.mda.gov.br/sitemda/plano-safra-da-agricultura-familiar-20172020> Acesso em: 06 jul. 2019.

CAMACHO, R. S. Por uma Agricultura Camponesa. Cadernos de Agroecologia, v. 11, n. 2, dec. 2016. Disponível em: <http://revistas.abaagroecologia.org.br/index.php/cad/article/view/21760>. Acesso em: 27 nov. 2020.

CARVALHO, H. M.; COSTA, F. A. Agricultura Camponesa. In: CALDART, R. S. et al. (Orgs.). Dicionário da Educação do Campo. Rio de Janeiro: Escola Politécnica de Saúde Joaquim Venâncio; São Paulo: Expressão Popular, 2012. p. 28-34.

CORRÊA, V. P.; ORTEGA, A. C. Pronaf: Programa Nacional de Fortalecimento da Agricultura Familiar - qual o seu real objetivo e público-alvo? Anais. SOBER (Sociedade Brasileira de Economia e Sociologia Rural), Passo Fundo, julho de 2002.

COSTA, F. A. Formação agropecuária da Amazônia: os desafios do desenvolvimento sustentável. Belém: Núcleo de Altos Estudos Amazônicos, Universidade Federal do Pará, 2000.

FERNANDES, B. M. Acampamento. In: CALDART, R. S. et al. (Orgs.). Dicionário da Educação do Campo. Rio de Janeiro: Escola Politécnica de Saúde Joaquim Venâncio; São Paulo: Expressão Popular, 2012. p. 23-27.

LEITE, S. P.; MEDEIROS, L. S. Agronegócio. In: CALDART, R. S. et al. (Orgs.). Dicionário da Educação do Campo. Rio de Janeiro: Escola Politécnica de Saúde Joaquim Venâncio; São Paulo: Expressão Popular, 2012. p. 81-87.

MATTEI, P. Políticas de Apoio ao Desenvolvimento da Agricultura Familiar no Brasil: O Caso Recente do Pronaf. Revista Econômica do Nordeste, Fortaleza, v. 38, no 1 , jan.-mar. 2007. p. 143-158.

MOLINA, M. C. Políticas Públicas. In: CALDART, R. S. et al. (Orgs.). Dicionário da Educação do Campo. Rio de Janeiro: Escola Politécnica de Saúde Joaquim Venâncio; São Paulo: Expressão Popular, 2012. p. 587-595.

SCHNEIDER, S.; MATTEI, L.; CAZELLA, A. A. Histórico, caracterização e dinâmica recente do PRONAF - Programa Nacional de Fortalecimento da Agricultura Familiar. 
CONSIDERAÇÕES ACERCA DO PROGRAMA NACIONAL DE FORTALECIMENTO DA AGRICULTURA FAMILIAR (PRONAF) NO PROJETO DE ASSENTAMENTO SANTA ROSA EM ITAQUIRAÍ - MS

In: SCHNEIDER, S.; SILVA, M. K.; MARQUES, P. E. Moruzzi (Org.). Políticas Públicas e Participação Social no Brasil Rural. Porto Alegre: 2004. p. 21-50.

SILVA, A. G. ARAUJO, J. P. O Dilema da Assessoria em Assentamentos Rurais: entre o ideal concebido e o real praticado. Revista Extensão Rural, DEAER/CPGExR - CCR - UFSM, Ano XV, Jan./Jun. 2008.

SILVA, D. A. Agroecologia como possibilidade de (re) produção no assentamento rural Sul Bonito em Itaquiraí-MS. Cadernos de Agroecologia, v. 9, n. 4, feb. 2015. Disponível em: $\quad$ <ttp://revistas.aba-agroecologia.org.br/index.php/cad/article/view/16416>. Acesso em: 27 nov. 2020. 
CONSIDERAÇÕES ACERCA DO PROGRAMA NACIONAL DE FORTALECIMENTO DA AGRICULTURA FAMILIAR (PRONAF) NO PROJETO DE ASSENTAMENTO SANTA ROSA EM ITAQUIRAÍ - MS

\section{APÊNDICE}

1- Questionário Semiestruturado aplicado aos camponeses do Projeto de Assentamento Santa Rosa em Itaquiraí - MS.

1. Nome

2. Idade: Número do Lote

3. Tem Declaração de aptidão ao PRONAF ( ) Sim ( ) Não

4. Sempre morou na roça? ( ) Sim ( ) Não

5. Onde nasceu (município)?

6. Qual sua última procedência, antes de chegar no assentamento?

7. Ficou acampado ( ) Sim ( ) Não ? Quanto Tempo

8. Qual foi o motivo que levou a acampar?

9. Tamanho do lote

10. Quanto tempo mora no assentamento

11. Já mudou de lote de lote? ( ) Sim ( ) Não

12. Por quê?

13. Está contente com a área recebida? (com o tamanho do lote) ( ) sim ( ) não Porque?

14. Quantas pessoas moravam no sítio, no início do assentamento?

15. E atualmente quantas pessoas moram hoje e trabalham no lote?

\begin{tabular}{|c|c|}
\hline Gênero & Faixa etária \\
\hline & \\
\hline & \\
\hline & \\
\hline
\end{tabular}


CONSIDERAÇÕES ACERCA DO PROGRAMA NACIONAL DE FORTALECIMENTO DA AGRICULTURA FAMILIAR (PRONAF) NO PROJETO DE ASSENTAMENTO SANTA ROSA EM ITAQUIRAÍ - MS

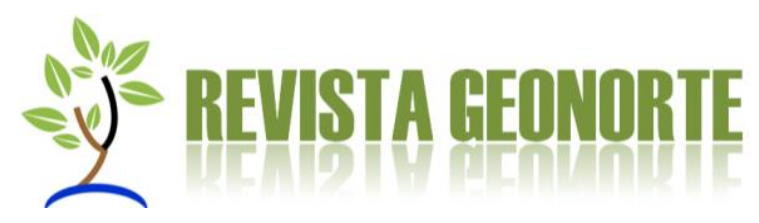

16. Escolaridade da família

\begin{tabular}{|l|c|c|c|c|c|}
\hline \multicolumn{5}{|c|}{ Escolaridade } \\
\hline $\begin{array}{c}\text { Membro } \\
\text { da família }\end{array}$ & $\begin{array}{c}\text { Ensino } \\
\text { fundamental } \\
\text { incompleto }\end{array}$ & $\begin{array}{c}\text { Ensino } \\
\text { fundamental } \\
\text { completo }\end{array}$ & $\begin{array}{c}\text { Ensino } \\
\text { médio } \\
\text { incompleto }\end{array}$ & $\begin{array}{c}\text { Ensino } \\
\text { médio } \\
\text { completo }\end{array}$ & Ensino superior \\
\hline Pai & & & & & \\
\hline Mae & & & & & \\
\hline Filho & & & & & \\
\hline Filho 2 & & & & & \\
\hline Nora & & & & & \\
\hline & & & & & \\
\hline & & & & & \\
\hline
\end{tabular}

17. Todos trabalham no sítio ou alguém trabalha fora em outra atividade? Atividade exercida:

\begin{tabular}{|l|l|l|}
\hline Atividade & $\begin{array}{l}\text { Quantidade de horas na } \\
\text { semana }\end{array}$ & Em média o R\$ \\
\hline Diarista & & \\
\hline Mensalista & & \\
\hline Funcionário publico & & \\
\hline Motorista de ônibus & & \\
\hline Professor & & \\
\hline & & \\
\hline
\end{tabular}

18. Há contratação de mão-de-obra temporária para desempenhar alguma atividade no sítio?

( ) sim ( ) não Para que?

\section{SOBRE O LOTE}

19. Quais as culturas e quantidade de hectares que são destinadas para a produção?

\begin{tabular}{|l|l|l|}
\hline Culturas & \multicolumn{1}{|c|}{ Hectares } & $\begin{array}{l}\text { Destino } \\
\text { consumo }\end{array}$ \\
\hline Algodão & & \\
\hline Mandioca & & \\
\hline Melancia & & \\
\hline Milho & & \\
\hline Abóbora & & \\
\hline Melão & & \\
\hline Soja & & \\
\hline Milho & & \\
\hline feijão & & \\
\hline Hortaliças & & \\
\hline & & \\
\hline
\end{tabular}


CONSIDERAÇÕES ACERCA DO PROGRAMA NACIONAL DE FORTALECIMENTO DA AGRICULTURA FAMILIAR (PRONAF) NO PROJETO DE ASSENTAMENTO SANTA ROSA EM ITAQUIRAÍ - MS

20. Quais os animais que são criados em seu sítio?

\begin{tabular}{|l|l|l|}
\hline Animais & Hectares & Destino comercio/ consumo \\
\hline Bovinos & & \\
\hline Carneiro & & \\
\hline Bicho da seda & & \\
\hline Apicultura & & \\
\hline Suínos & & \\
\hline Galinhas & & \\
\hline & & \\
\hline
\end{tabular}

21. Quais são os sistemas e as técnicas de cultivo utilizados no sitio?

\begin{tabular}{|l|l|l|l|l|}
\hline Sistemas e técnicas & Sim & Não & $\begin{array}{l}\text { As } \\
\text { vezes }\end{array}$ & Observações \\
\hline calcário & & & & \\
\hline Adubos químico & & & & \\
\hline Adubo orgânico & & & & \\
\hline Adubo verde & & & & \\
\hline $\begin{array}{l}\text { Caldas } \\
\text { agroecológicas }\end{array}$ & & & & \\
\hline Urina de Vaca & & & & \\
\hline Arado com cavalo & & & & \\
\hline Plantadeira manual & & & & \\
\hline $\begin{array}{l}\text { Plantadeira } \\
\text { mecânica }\end{array}$ & & & & \\
\hline Ordenha mecânica & & & & \\
\hline Ordenha manual & & & & \\
\hline Utiliza inseticidas & & & & \\
\hline Utiliza fungicida & & & & \\
\hline $\begin{array}{l}\text { Utiliza dessecante de } \\
\text { mato }\end{array}$ & & & & \\
\hline Sementes crioulas & & & & \\
\hline Sementes híbridas & & & & \\
\hline $\begin{array}{l}\text { Faz consorcio de } \\
\text { culturas }\end{array}$ & & & & \\
\hline $\begin{array}{l}\text { Faz rotação de } \\
\text { culturas }\end{array}$ & & & & \\
\hline \multicolumn{1}{|c|}{} & & & & \\
\hline
\end{tabular}


CONSIDERAÇÕES ACERCA DO PROGRAMA NACIONAL DE FORTALECIMENTO DA AGRICULTURA FAMILIAR (PRONAF) NO PROJETO DE ASSENTAMENTO SANTA ROSA EM ITAQUIRAÍ - MS

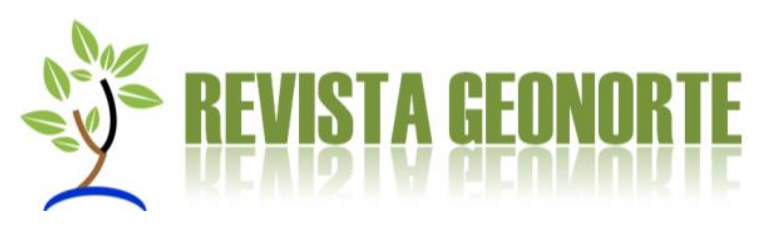

22. Quais são os locais onde é comercializada a produção do sítio?

\begin{tabular}{|l|l|l|l|l|l|l|}
\hline Produto & PNAE & PAA & Atravessador & Feira & Mercado & Venda domicílio \\
\hline Feijão & & & & & & \\
\hline Mandioca & & & & & & \\
\hline Leite in natura & & & & & & \\
\hline Hortaliças & & & & & & \\
\hline & & & & & & \\
\hline & & & & & & \\
\hline & & & & & & \\
\hline & & & & & & \\
\hline
\end{tabular}

23. Já obtiveram financiamentos de banco? ( ) Sim ( )

Não Por quê?

24. Ano do último financiamento e Valor

25. Se financiou, qual foi a finalidade?

(a) Compra de animais: bovinos de corte ( ), bovinos de leite ( ), galinhas ( ), ovelhas ()

(b) Custeio de lavouras: milho ( ), feijão( ), arroz ( ), mandioca ( ), algodão ( ), soja ( )

(c) Infraestrutura: caixa d'água ( ), currais ( ), cerca ( ), carroças ( )

(d) Pastagem: Plantio pastagens ( ) Renovação de pastagens ( )

(e) Equipamentos: trator ( ), plantadeira ( ), grade ( ), arado( ), centrífuga( ), kits de apicultura ( ). ( ) Compra de insumos ( ) Pagamento de serviços

( f)

26. Qual foi a via de financiamento? (indicar as letras da questão anterior, quando for o caso).

( ) Caixa econômica Federal -:

( ) Banco do Brasil - Pronaf

( ) Cresol -

( ) Investimento pessoal

27. Quitou o financiamento ( ) Sim ( ) Não

qual o motivo

28. Ao contratar os créditos como foi a liberação dos recursos?

29. A equipe técnica de extensão rural ajudou na orientação aonde era possível adquirir os produtos, ferramentas, materiais, bovinos, sementes? 
30. Como o você avalia o PRONAF? E se pudesse dar algumas sugestões de melhorias no programa o que você mudaria?

31. Depois de acessar o crédito do PRONAF sua produção do sítio aumentou?

( ) Aumentou

( ) Diminuiu

( ) Permaneceu igual

32. Nos dias atuais, você conseguiria manter suas atividades de produção no sítio sem acessar créditos do Pronaf?

( ) Sim ( ) Não

33. Você é associado (a) a cooperativa ou entidade de classe?

( ) Cooperativa ( ) Entidade de classe - sindicato ( )Associações / movimentos produtores(as)

( ) Associações de moradores(as)

34. Você participa de algum conselhos ( ) Sim （） Não quais

35. Qual é seu sonho na vida? 